\title{
Business Model Evolution of Customer Care Services
}

\author{
Jukka Majava (iD), Ville Isoherranen(iD) \\ University of Oulu (Finland) \\ juk.ka.majava@oulu.fi,ville.isoherranen@oulu.fi
}

Received: August 2018

Accepted: November 2018

\begin{abstract}
:
Purpose: Servitization is a rising trend as companies look for new revenue streams. This paper presents a study of customer care business model evolution in the smartphone industry. The paper identifies key changes in the business models during recent years and their implications for companies seeking after-sales service excellence and new revenue sources.

Design/methodology/approach: The research approach is built on the literature of product-service offerings, servitization, and business models. The empirical part is based on a case study of former Nokia mobile phone business, the Apple iPhone, and Google Android.
\end{abstract}

Findings: Three different customer care business models and an analysis of the changes in the smartphone industry are presented. This paper demonstrates how after-sales services have become increasingly important in generating new revenue. Moreover, the nature of after-sales services has fundamentally changed in the industry.

Research limitations/implications: Due to the careful selection of the cases that represent the studied industry well, the results provide valuable insights for practitioners and researchers involved in developing after-sales service offerings in the mobile industry. However, a case study research approach may not offer a generalized picture of this phenomenon in other industries.

Originality/value: A novel analysis of customer care evolution in the smartphone industry is presented. In addition, the study demonstrates that applying the concept of business models to after-sales services provides new insights into these services and their roles in business.

Keywords: customer care, after-sales, business model, services management, operations management, servitization

\section{To cite this article:}

Majava, J., \& Isoheranen, V. (2019). Business model evolution of customer care services. Journal of Industrial Engineering and Management, 12(1), 1-12. https://doi.org/10.3926/jiem.2725

\section{Introduction}

The increasing servitization of business has become a global trend; companies are having to look for new revenue streams since global competition has decreased the margins of a purely physical product-based business (Oliva \& Kallenberg, 2003; Tien, 2015). In addition, service quality has become increasingly important in many industries (Roy, Lassar, Ganguli, Nguyen \& Yu, 2015). In the past, many companies used post-sale customer services solely for warranty cost and reverse logistics cost minimization and these services were not seen as an opportunity for revenue generation. Warranty cost and reverse logistics cost optimization have been extensively studied in the 
academic literature (e.g., Balcer \& Sahin, 1986; Kim \& Rao, 2000; Chattopadhyay \& Murthy, 2000; Pellicer \& Valero, 2018). Warranty related services were, in many cases, outsourced to an external cost-optimized service network and they were not seen as a core activity by businesses (Majava, Harkonen \& Haapasalo, 2015; Majava \& Isoherranen, 2016). However, traditional product-centric business models are now challenged by new product-service offerings, and in many cases these new, more complete, offerings are winning. Thus, product-based firms need to quickly learn and develop new ways of developing their business, that is, their business model in customer care services must be revisited.

This study examines the smartphone industry, where extreme global business competition and fast technology cycles create an interesting research environment (Isoherranen \& Kess, 2011); many new phenomena and their effects can be examined in this space first. New products and services need to be brought to market rapidly, and typically in the digital business, the fastest takes it all, grabbing the highest market and profit shares. The time to market is therefore of essence. From the news that have been seen in the business world, these fast market introductions also have customer care related risks. An example of this the Samsung Galaxy Note 7 battery case in 2016, which eventually led to shutting down production, recalling products, and creating lasting damage to the brand and customer experiences. All of these resulted in high losses for the company.

During recent years, customer preferences have changed in the mobile phone market (Haverila, 2011), which has made the business more dynamic. Today's customers are more willing to accept that a product can have software issues, tolerate frequent updates, and understand that the product may break when it is dropped. Self-service using discussion forums or interacting with customer service agents or chat-robots through chat are standard practices among companies. These new preferences, along with rapid technology evolution, have created disruptions of the traditional product-centric business models. And at the same time, this provides agile companies with new business opportunities. Digitalization opens zero-cost opportunities to interact with customers by using new tools (i.e., WhatsApp, WeChat) (Ibrahim, Ros, Sulaiman, Nordin \& Ze, 2014), as well as to collect data, learn, and serve customers better than ever before. Every contact with the customer is a sales opportunity in the digital world. To be able to capitalise on this opportunity, product-centric companies face a challenge in transforming their traditional external service networks, business models, and operating models toward new demands.

In spite of the extensive research on customer services (e.g., Heinonen, Strandvik, Mickelsson, Edvardsson, Sundström \& Andersson, 2010; Lewis, 1988), the changes in after-sales service (customer care) business models have not been adequately addressed in the academic research. The purpose of this paper is to study how after-sales service business models have evolved from the traditional customer care business model for physical products (Nokia smartphone business) to a physical-service combination (Apple iPhone) and to a pure software and service model (Google Android). This study aims to answer the following research questions (RQs):

RQ1: What key changes in the customer care business models have occurred in the smartphone industry in recent years?

RQ2: What are the possible implications of these changes for companies in the industry and how can customer care excellence be achieved in the future?

The article is structured as follows. Section 2 includes the literature background and section 3 describes the research process. Section 4 presents the empirical findings and the analysis of the results. Section 5 discusses the findings, and Section 6 presents conclusions.

\section{Literature Background}

\subsection{Products, Services and Servitization}

Products and services are outputs of productional activity. According to Kahn (2001), a product is an offering that a company provides to its customers. Ulrich and Eppinger (2000) define product as something that a firm sells to the customers. Cooper (2011), in turn, sees that a product is anything provided for sale, use, or consumption in an external marketplace. The aforementioned includes both tangible products and services, and their combinations. However, services differ from physical products in many ways. According to Kotler and Keller (2009), services are intangible acts or performances that one party can offer to another. These acts or performances do not result in the 
ownership of anything, although they may also be tied to tangible products. Services are claimed to have four distinct characteristics. They are intangible, inseparable (produced and consumed simultaneously), variable (quality depends on who provides them, when, where, and to whom), and perishable (cannot be stored).

Krishnan and Ulrich (2001) highlight four different perspectives on the product in academic research: 1) in marketing, the product is a bundle of attributes; 2) for organizations, the product is an artefact resulting from an organizational process; 3 ) in engineering design, the product is a complex assembly of interacting components; and 4) in operations management, the product is a sequence of development and/or production process steps. Operations management for physical products typically aims for standard processes and resource efficiency, whereas operations management for services is more based on interactions with customers, customization, and flexibility (Krajewski, Ritzman \& Malhotra, 2013). Nowadays, organizations that solely produce physical products are rare, because many physical products create a need for supporting services, such as technical support, customer service, manuals, or maintenance (Slack, Chambers \& Johnston, 2010).

Offering services may improve a company's competitiveness, but transforming an organization from a provider of tangible products to a service provider may be difficult due to, for example, cultural issues and organizational resistance (Benyoussef-Zghidi \& Zaiem, 2017; Martinez, Bastl, Kingston \& Evans, 2010). Servitization is a change process where a company transforms its offerings from tangible products to product-service offerings (Martinez et al., 2010). Servitization enables a company to create more value for its customers, develop a more valuable business, and offer tailored solutions to the customers. The focus is on the use of the offering instead of just owning it; the goal is to increase value and reduce material and other costs (Baines, Lightfoot, Peppard, Johnson, Tiwari, Shehab et al., 2009). Vargo and Lusch (2008) present two different approaches in transitioning from goods to services: goods-dominant logic that considers services in terms of a type of good and service-dominant logic that views service as the fundamental purpose of economic exchange. The first logic suggests that production and distribution practices must be altered to deal with the differences between tangible goods and services, whereas the latter logic assumes that there exists a need for a revised, service-driven framework for marketing (Vargo \& Lusch, 2008). In any case, offering new services requires investments and may not always be profitable for companies (Neely, 2009).

\subsection{After-Sales Services and Business Models}

Customer services include various dimensions whose importance is dependent on the industry. These dimensions can include pre-sales service, delivery dependability and speed, product technical support (after-sales service), and responsiveness to customer queries, among others. Customer service and firm performance have been found to have a positive correlation (Vickery, Jayaram, Droge \& Calantone, 2003). In this paper, the use of the term "customer services" focuses on after-sales services. The supply chain for after-sales differs from production supply chain in terms of nature of demand, response times, performance metrics, the amount of products, delivery network, reverse logistics, and inventory management (Cohen, Agrawal \& Agrawal, 2006; Iraqi, Barkany \& Biyaali, 2016; Puurunen, Majava \& Kess, 2014).

A natural way for a company to expand its offering to services is to start offering product support services. Lele and Karmakar (1983) provide a broad definition of product support; it covers everything that can increase the customer's after-sales satisfaction, including spare parts and spare parts delivery, service, warranty, user and maintenance training, reliability and serviceability engineering, and even product design. According to Cohen et al. (2006) the transition from products to solutions has provided opportunities for gaining new sources of revenues from selling spare parts and after-sales services, i.e. carrying out repairs, installing upgrades, reconditioning equipment, conducting inspections and day-to-day maintenance, providing technical support, consulting, and training, and arranging finances. After-sales activities can be important for a company's image, customer satisfaction, and customer retention (Saccani, Songini \& Gaiardelli, 2006). Thus, the customer service experience in the after-sales phase should be carefully considered when a company designs its business model. Cohen et al. (2006) has categorized customer care business models based on service priorities, terms, and product owners. The models range from disposal (e.g. razor blades) to power by the hour (e.g. aircraft engines). However, it should also be acknowledged that the models are often industry-dependent. 
The term "business model" is commonly used among industry practitioners, although it may mean different things to different people. According to Hamermesh, Marshall and Pirmohamed (2002), a business model can be defined as "a summation of the core business decisions and trade-offs employed by a company to earn a profit". Furthermore, these business decisions and trade-offs fall into the following four groups: revenue sources, key expenses, investment size, and critical success factors. On the other hand, Osterwalder and Pigneur (2010) state that "a business model describes the rationale of how an organization creates, delivers, and captures value." The business model can be described with a canvas consisting of nine different elements: value propositions, customer segments, channels, customer relationships, revenue streams, key resources, key activities, key partners, and cost structure. The company's business model can be described by defining all nine elements to gain understanding about the essential elements for the company's success. The relationships between these elements are also important (Osterwalder \& Pigneur, 2010). According to Johnson, Christensen and Kagermann (2008), the elements of a successful business model include customer value propositions (target customer, job to be done, and offering), profit formulas (revenue model, cost structure, margin model, and resource velocity), key resources (e.g., people, technology, products, equipment, information, channels, partnerships, alliances, and brand), and key processes (e.g., processes, rules and metrics, and norms).

Osterwalder and Pigneur (2010) describe the business model elements as follows. Value propositions define what product and service bundles are offered to each customer segment. More specifically, "the value proposition is an aggregation, or bundle, of benefits that a company offers customers" (Osterwalder \& Pigneur, 2010: page 22). These values can be quantitative (e.g. price, speed of service) or qualitative, such as design or customer experience. (Osterwalder \& Pigneur, 2010). In this paper the term value proposition describes the service offering from customers' perspective. Customer segments define the groups of people or organizations that the company aims to serve. Channels, in turn, describe which methods are used to reach and communicate with these customers, whereas customer relationships define the relationship types a company establishes with each customer segment. The cash that a company generates from these customer segments is represented by revenue streams. Key resources define the key assets that are required to make the business model functional, whereas key activities describe the critical things to perform. The supplier and partner network needed for the business model is described by the key partnerships element. Finally, cost structure articulates all costs incurred in operating the business model. (Osterwalder \& Pigneur, 2010).

\section{Method}

This study explores customer care business model evolution in the smartphone industry. Due to the real-life context and the complexity of the studied phenomenon, a qualitative research approach and a case study method (Yin, 2009) was deemed the most appropriate research strategy. A case study is an empirical inquiry that studies a phenomenon within its real-life context to gain understanding of the phenomenon either by learning something about the case itself or to achieve a broader understanding (Yin, 2009). The literature base for the study was built by examining the following concepts: the characteristics of tangible products and services, servitization and its effects on companies' operations, after-sales services, and business models. The empirical data collection was implemented by using observational field research. The empirical data for the three cases (Nokia, Apple, and Google) analyzed in this study were acquired through three different sources. The Nokia related empirical data were mainly collected between 2007 and 2010. During that time the researchers worked in managerial roles in Nokia's customer care services, i.e. action research was employed in the data collection. The Apple and Google related empirical data, in turn, were collected from public sources (i.e. Internet and the companies' websites). In addition, the researchers used the products of the case companies to analyze their customer care services.

The case selection criterion was market leadership in the smartphone industry. The smartphone market began to change in 2007, when Apple introduced its first iPhone product. Since then, the roles of user interface, applications and services started to increase dramatically in the industry. Nokia was the market leader between 2007 and 2010 , followed by Google Android beginning in 2011, and Apple iPhone has had the second largest market share since 2011 (Statista, 2017). The empirical data were analyzed by utilizing a qualitative approach and the literature findings, and the results and implications were documented. The research process is described in Figure 1. 


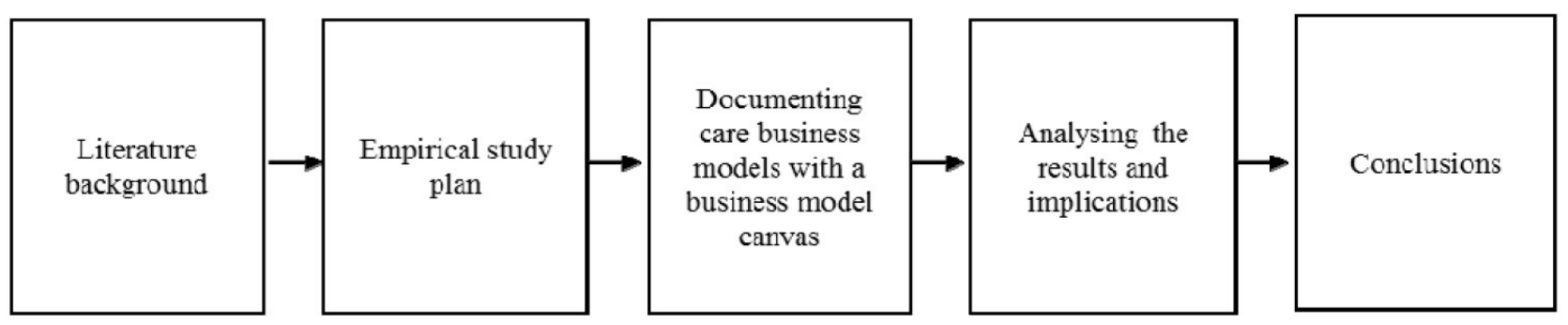

Figure 1. Research process

\section{Results}

\subsection{Case 1: Nokia's Smartphone Business}

Case 1 describes Nokia's smartphone customer care business model in years 2007-2010. In this analysis, Nokia's after-sales service business model is described by using the following elements based on the framework by Osterwalder and Pigneur (2010): customer segments, value propositions, channels, customer relationships, revenue streams, key resources, key activities, key partners, and cost structure. Table 1 describes Nokia's customer care business model.

\begin{tabular}{|c|c|}
\hline Business model element & Description \\
\hline Value propositions & $\begin{array}{l}\text { Warranty and out-of-warranty repairs and SW updates } \\
\text { Solving customer's product usage related problems } \\
\text { Self-service troubleshooting, FAQs, instructions }\end{array}$ \\
\hline Customer segments & Mass market (consisting of different segments), the same services are provided to all segments \\
\hline Channels & $\begin{array}{l}\text { Authorized 3rd party service points } \\
\text { Outsourced call centers } \\
\text { Nokia.com/support website }\end{array}$ \\
\hline Customer relationships & $\begin{array}{l}\text { Transaction based } \\
\text { No information on the customer. Loyalty and repurchase targeted through "good enough" } \\
\text { quality and service. }\end{array}$ \\
\hline Revenue streams & $\begin{array}{l}\text { No revenue (phone tolls cover some costs in certain countries) } \\
\text { Warranty cost minimization the main target }\end{array}$ \\
\hline Key resources & $\begin{array}{l}\text { Customer service teams in product development and sales areas } \\
\text { Logistics network for service tools, spare parts, SW, information (instructions and field } \\
\text { feedback), training, and failed products }\end{array}$ \\
\hline Key activities & $\begin{array}{l}\text { Care capability creation in product development } \\
\text { Care capability creation, deployment, and maintenance in sales areas } \\
\text { Daily repair and support operations }\end{array}$ \\
\hline Key partners & $\begin{array}{l}\text { 3rd party service points and call centers } \\
\text { Service tool providers } \\
\text { Companies providing technical writing services }\end{array}$ \\
\hline Cost structure & $\begin{array}{l}\text { R\&D costs in product development } \\
\text { Capability creation, deployment, and maintenance in sales areas } \\
\text { Network maintenance } \\
\text { Call center costs based on transactions } \\
\text { Warranty costs based on repairs and swaps }\end{array}$ \\
\hline
\end{tabular}

Table 1. The analysis of Nokia's customer care business model based on the framework by Osterwalder and Pigneur (2010)

Nokia's market is the mass market, which includes several customer segments ranging from low-income to high-income consumers. However, the customer services are not tailored, which means that the same services are provided to all segments. The value proposition includes the following elements: warranty and out-of-warranty repairs and software updates, solving a customer's product usage related problems, self-service troubleshooting, 
frequently asked questions (FAQs), and instructions. The value proposition is offered through authorized 3rd party service points, outsourced call centers, and the Nokia.com/support website. Customer relationships, in turn, are mostly transaction based, and information on the customer is missing, insufficient, or not utilized. Customer loyalty and repurchases are targeted by providing "good enough" service quality. After-sales services are not seen as a revenue generator; the idea is solely to minimize warranty costs and cover some of the service costs, for example, by charging phone tolls when a customer contacts the call center for support.

The key resources in Nokia's customer care business model include customer service teams in product development and sales area organizations, as well as a forward and reverse logistics network that is needed to transfer service tools, spare parts, software, information (instructions and field feedback), training materials, and failed and replacement products. These key resources are needed to perform the following key activities: care capability creation in product development; care capability creation, deployment, and maintenance in sales areas; and daily repair and support operations. Key partners entail 3rd party service points and call centers, service tool providers, and companies providing technical writing services for service manuals and guides. The main cost elements in Nokia's customer care business model include R\&D costs in product development department; service capability creation, deployment, and maintenance in sales areas; network maintenance; transaction-based call center costs (not charged to the customers in every country); and warranty costs based on the number of repairs and replaced products.

\subsection{Case 2: Apple iPhone}

Apple iPhone's after-sales service business model differs from Nokia in many ways. Table 2 illustrates the model.

\begin{tabular}{|c|c|}
\hline Business model element & Description \\
\hline Value propositions & $\begin{array}{l}\text { Excellent customer experience in problem cases } \\
\text { Value-added services (e.g., applications, music, iCloud's capability to share content with all } \\
\text { Apple devices) } \\
\text { Product upgrade capability through self-service SW updates } \\
\text { AppleCare Protection Plan (extended warranty, easy product returns, free technical support) }\end{array}$ \\
\hline Customer segments & Mass market (high price category) \\
\hline Channels & $\begin{array}{l}\text { Apple stores } \\
\text { Authorized 3rd party service providers } \\
\text { Chat and phone support } \\
\text { support.apple.com, iTunes, AppStore, iCloud, OS update notifications } \\
\text { User-based online support community }\end{array}$ \\
\hline Customer relationships & $\begin{array}{l}\text { Close, continuous customer relationships } \\
\text { Detailed information on the customers and their preferences }\end{array}$ \\
\hline Revenue streams & $\begin{array}{l}\text { Substantial revenue from value-added services (iTunes, AppStore, iCloud) } \\
\text { Additional revenue from AppleCare Protection Plan }\end{array}$ \\
\hline Key resources & $\begin{array}{l}\text { SW developers } \\
\text { Online platform and data storage }\end{array}$ \\
\hline Key activities & $\begin{array}{l}\text { SW development for the bug fixes/OS updates and online services } \\
\text { Online service capability creation, deployment, and maintenance } \\
\text { Daily customer service operations }\end{array}$ \\
\hline Key partners & Certified 3rd party service providers \\
\hline Cost structure & $\begin{array}{l}\text { Personnel salaries (SW developers, etc.) } \\
\text { Online platform maintenance } \\
\text { Reverse logistics }\end{array}$ \\
\hline
\end{tabular}

Table 2. The analysis of Apple iPhone's customer care business model based on the framework by Osterwalder and Pigneur (2010) 
First of all, while the iPhone is targeted to the mass market, the customer segment is mostly high-income consumers. Apple's value proposition includes excellent customer experiences in problem cases, value-added services (e.g., applications, music, and the iCloud, which provides the capability to share content with all Apple devices), and product upgrade capability through self-service SW updates. An optional AppleCare Protection Plan provides an extended warranty, easy product returns, and free technical support. The value proposition is offered through Apple stores, authorized 3rd party service providers, chat and phone support, support.apple.com, iTunes, the AppStore, iCloud, OS update notifications on the phone's display, and a user-based online support community. Customer relationships are close and continuous, and detailed information on the customers and their preferences is gathered. This information can be used for both Apple's and the customer's benefit. Customer services generate significant revenue streams: substantial revenue is created from value-added services (e.g., iTunes, the AppStore), whereas the AppleCare Protection Plan generates additional revenue.

Key resources in Apple's customer care business model include software developers, an online platform, and data storage. The key activities include software development for bug fixes, operating system (OS) updates, and online services, as well as online service capability creation, deployment, and maintenance. Daily customer service operations are also important, but most of the key activities take place online. The customer's service experience is mostly based on the online delivery that is controlled by Apple, thus the number of key partners is lower than in Nokia's case. Yet, certified 3rd party service providers can be considered to be important partners in Apple's model. The main cost elements include personnel salaries (especially for software developers), online platform maintenance, and reverse logistics for failed products.

\subsection{Case 3: Google Android}

Similar to Nokia, Google's Android is targeted to the mass market, which includes several customer segments ranging from low-income to high-income consumers. However, for Google, the product is the operating system and the customer care value proposition differs from both Nokia's and Apple's propositions. The business model is described in Table 3.

\begin{tabular}{|l|l|}
\hline Business model element & \multicolumn{1}{|c|}{ Description } \\
\hline Value propositions & $\begin{array}{l}\text { Product release (e.g., Lollipop) continuously updates so that customers use only the latest } \\
\text { releases with the best possible support } \\
\text { Largest possible active user base as a means to get revenue from services (Search, Google Play) } \\
\text { Online self-help, tutorials, and 24 x 7 community } \\
\text { Hardware support provided by the OEMs }\end{array}$ \\
\hline Customer segments & Mass market (every price category) \\
\hline Channels & $\begin{array}{l}\text { support.google.com/android } \\
\text { Automatic small updates, e.g., for Lollipop release }\end{array}$ \\
\hline Customer relationships & $\begin{array}{l}\text { Intimate information on the customers based on their searches, locations, etc. } \\
\text { High switching costs; customer lock-in through Gmail, Google Drive, Google Docs, etc. }\end{array}$ \\
\hline Revenue streams & $\begin{array}{l}\text { Advertising (e.g., Search) and services (e.g., Play) revenue. No revenue from customer support; } \\
\text { the logic is different. Revenue is based on the large active user base that has their SW up and } \\
\text { running. }\end{array}$ \\
\hline Key resources & $\begin{array}{l}\text { SW developers } \\
\text { Online platform and data storage }\end{array}$ \\
\hline Key activities & $\begin{array}{l}\text { SW development for bug fixes/application update/OS updates and online services } \\
\text { Online service capability creation, deployment, and maintenance }\end{array}$ \\
\hline Key partners & $\begin{array}{l}\text { 3rd party application developers and communities } \\
\text { OEM manufacturers }\end{array}$ \\
\hline Cost structure & $\begin{array}{l}\text { Personnel salaries (SW developers) } \\
\text { Online platform maintenance }\end{array}$ \\
\hline
\end{tabular}

Table 3. The analysis of Google Android's customer care business model based on the framework by Osterwalder and Pigneur (2010) 
Google targets the mass market by offering a continuously up-to-date OS release (e.g., Lollipop), so that customers will use only the latest releases with the best possible support. Google aims to have the largest possible active user base in order to get revenue from services (e.g., Search, Google Play). The value proposition includes online self-help, tutorials, and a community with 24 hours, 7 days a week support. Hardware support is delegated to the original equipment manufacturers (OEMs, such as Huawei). The support channels include support.google.com/android and automatic incremental updates through the device. Customer relationships are intimate; Google knows the customers and their preferences based on their use of search, location, and other services. In addition, the switching costs are high; customer lock-in is ensured through Gmail, Google Drive, Google Docs, and other services. Google's revenue sources include advertising (e.g., Search) and services (e.g., Play). Customer support is not a revenue generator per se, since the overall business model is based on the largest possible active user base that will always have up-to-date software.

Key resources in Google's after-sales service business model include software developers, an online platform, and data storage. The key activities, in turn, include software development for the bug fixes, application updates, OS updates, and online services. Online service capability creation, deployment, and maintenance can also be seen as a key activity. Key partners in Google's customer care model include 3rd party application developers and communities, as well as OEM manufacturers that are critical for hardware related support. Finally, the main cost elements include software developers' salaries and online platform maintenance costs.

\subsection{Key Changes in the Customer Care Business Models}

As the three cases analyzed in this study illustrate, customer care business models have evolved fundamentally in the smartphone industry. Table 4 provides a summary of the key changes in the after-sales service business models.

As Table 4 illustrates, all the business model elements have changed dramatically. The after-sales support has been integrated with total service offerings and the customers have become identified. The nature of distribution has changed from physical to online delivery and the relationships have become continuous and intimate. The aforementioned elements have enabled the creation of new revenue streams from the services in the after-sales phase. Large changes have also occurred in key resources, key activities, key partners, and costs.

\begin{tabular}{|l|l|}
\hline Business model element & \multicolumn{1}{c|}{ Description } \\
\hline Value propositions & $\begin{array}{l}\text { From warranty cost optimization to integrated after-sales support and service offerings (e.g., } \\
\text { extended warranty and value-added services) }\end{array}$ \\
\hline Customer segments & From an anonymous mass market to identified, unique customers \\
\hline Channels & From physical service delivery to online 24 x 7 support \\
\hline Customer relationships & From transaction based to a continuous and intimate customer relationship \\
\hline Revenue streams & From zero revenue to substantial service business \\
\hline Key resources & From physical supply chain network to software resource pool \\
\hline Key activities & From daily repair and support operations to online operations \\
\hline Key partners & From 3rd party service points to a software developer community \\
\hline Cost structure & From a physical supply chain network to online platform development and maintenance \\
\hline
\end{tabular}

Table 4. Summary of key changes in the customer care business models based on the framework by Osterwalder and Pigneur (2010)

\section{Discussion}

The study analyzed key changes in the customer care business models in the smartphone industry. The empirical case study included former Nokia smartphone business, the Apple iPhone, and Google Android. Based on the study's findings, Nokia's approach to after-sales services can be considered very traditional and it has been focused on warranty cost optimization (e.g., Balcer \& Sahin, 1986) and the reduction of the maintenance costs of the sold products. The after-sales services network was outsourced to 3rd party service providers as much as possible, and 
the business model was set to minimize the costs of customer interactions. A good example of this is the outsourced customer support call centers, which are either toll-free or fee-based as driven by local market customer legislation.

For the iPhone, Apple has taken a different approach to customer service interaction in the after-sales space. Apple has productized the warranty offering by selling an extra warranty, the AppleCare package, which extends the time period of when the customer can benefit from the full repair and support services from Apple or its licensed 3rd party service providers. Apple created an extra revenue stream from the after-sales services, and is not driven by cost optimization only. The aforementioned follows the logic of creating offerings that include both tangible and intangible components (e.g., Baines et al., 2009).

Google's Android customer service is provided online only. Google's Android offering is a pure SW experience; the tangible product is delivered to customers by OEMs, such as LG or Sony. The value proposition includes online self-help, tutorials, and a community with 24 hours, 7 days a week support. Hardware support is delegated to the OEMs. Google's approach provides an extreme example of a case where tangible and intangible offerings are co-produced with many parties (Tien, 2015).

From the examples presented in this study, it is clear that the key changes in the after-sales business models are fundamental. The study demonstrates that there exist a need to study the customer care business models with a specific framework, such as business model canvas (Osterwalder \& Pigneur, 2010), because the model presented by Cohen et al. (2006) is too generic to be used in the industry-specific analysis. In spite of the many challenges related to servitization (Benyoussef-Zghidi \& Zaiem, 2017; Martinez et al., 2010), the previously common simple warranty cost optimization (i.e., reducing the total cost of product maintenance) without a focus on customer experience is no longer a viable option in the smartphone business. The winners in this business are using every service and customer support interaction with customers as a new sales event; it is a possibility to learn about customer needs, and then fulfil these needs with an offering. More and more, these offerings are becoming a service or a bundle with combined products and services.

It is also interesting to note that the old way of maintaining legacy products and legacy software (i.e., old releases) is no longer considered profitable. The long tail of old products and software is becoming a liability for many companies. Introducing new features and services must happen quickly, and this forces companies to put their development resources into new services and product development. This is then seen in the after-sales services as phasing out old releases by simply not having any more customer support available for these older versions or releases. The customer is directed to update or re-buy the product or software in short intervals. If they do not buy the new version, the services or applications they are using may not be supported, might have limited functionalities, or may be exposed to information security risks due to the lack of updates.

There is also a growing demand from customers to once again have durable, reliable, and long-lasting products. One example of these almost nostalgic experiences was the huge demand for the legendary Nokia 3310 "relaunch" in 2017, which is still regarded as a highly durable product by customers. It will be interesting to see if this continues to be a growing desire of customers.

The implications of these changes for companies and how companies can achieve after-sales (customer care) excellence in the future are twofold. First of all, it is clear that technology cycles are faster in the mobile industry than ten years ago, and this forces companies in this business to focus their resources on new features and service development. But on the other hand, after-sales services have become substantial revenue streams; the change from warranty costs minimization to new business is dramatic. This change is supported by new technological capabilities, which enable service providers to collect identifiable customer data. The data can be used to create new business, improve customer experiences, and increase loyalty for re-purchase. Customer relationships have become more intimate, thus, for companies to succeed in this industry, they must combine the fast to market introductions of new services, and the winning services will most likely originate from the well-executed after-sales services in which customer preferences and insights are learned, analyzed, and used as input for the development of new services. Customer care excellence is the prerequisite for business excellence in the smartphone industry. 
The disruptions in the mobile industry have always been fast, so it is likely that this will also happen in the future. For companies to achieve future after-sales service excellence, the factors of new technology introductions, especially in the area of 3D printing (digital manufacturing, factories in the cloud concepts), need to be taken into account. These new capabilities can change the way after-sales services are provided to customers. The instant availability of spare parts, without the need to hold inventory (and without the operating costs related to holding extra inventory), can change the delivery of after-sales services. Trends such as sustainability, recycling, the consumers' right to repair claims and do-it-yourself (DIY) 3rd party repair kits, as well as the potentially rising protectionism against global trade in countries, such as USA and China, can call for the localization of service assets as customs and transport costs might increase. Digital delivery also gains extra support in this scenario. The information security concerns of having products that are not up to date might cause significant changes in customer preferences. An intimate customer focus is still the most significant driver for service excellence in the future and is also the prerequisite for new service business creation; every customer interaction in after-sales services can provide companies with significant value.

\section{Conclusions}

Servitization, that is, the change from a tangible product to a product-service offering, has become a global rising trend as companies seek new sources of income. This paper presented a case study of the evolution of the customer care business model in the smartphone industry. The study aimed to analyze key changes in the after-sales service business models during recent years. Furthermore, the implications of the aforementioned changes for companies seeking customer care excellence and new revenue sources were discussed. The empirical cases analyzed in this study were the former Nokia smartphone business, Apple's iPhone, and Google’s Android.

The key results of this study include an analysis of three different customer care business models and a summary of the changes in the industry. The customer care business models were analyzed in sections 4.1-4.3 and the key changes were presented in section 4.4. The findings of this study indicate that after-sales services have become increasingly important as a source of new revenue streams. Moreover, the role of customer support services has become fundamentally different in the smartphone industry during the past ten years.

This study demonstrates that applying the concept of business models to the analysis of after-sales services provides novel insights, both in terms of their evolution and their role in companies' offerings. The cases analyzed in this study were carefully selected based on the criterion of market leadership. Thus, the cases can be considered to represent the studied industry well and the results of this study may provide valuable insights for after-sales service practitioners and researchers in the mobile industry. Yet, due to the natural limitations of the case study method, the findings of this study may not be applicable in other industries. Therefore, the authors recommend conducting further research in other industries and organizations to validate the results and further expand the knowledge of customer care business models.

\section{Declaration of Conflicting Interests}

The authors declared no potential conflicts of interest with respect to the research, authorship, and/or publication of this article.

\section{Funding}

The authors received no financial support for the research, authorship, and/or publication of this article.

\section{References}

Baines, T., Lightfoot, H., Peppard, J., Johnson, M., Tiwari, A., Shehab, E. et al. (2009). Towards an operations strategy for product-centric servitization. International Journal of Operations \& Production Management, 29(5), 494-519. https://doi.org/10.1108/01443570910953603

Balcer, Y., \& Sahin, I. (1986). Replacement costs under warranty: Cost moments and time variability. Operations Research, 34(4), 554-559. https://doi.org/10.1287/opre.34.4.554 
Benyoussef-Zghidi, A., \& Zaiem, I. (2017). Service orientation as a strategic marketing tool: The moderating effect of business sector. Competitiveness Review: An International Business Journal, 27(1), 40-61. https://doi.org/10.1108/CR02-2015-0012

Chattopadhyay, G.N., \& Murthy, D.N.P. (2000). Warranty cost analysis for second-hand products. Mathematical and Computer Modelling, 31(10-12), 81-88. https:/ / doi.org/10.1016/S0895-7177(00)00074-1

Cohen, M.A., Agrawal, N., \& Agrawal, V. (2006). Winning in the aftermarket. Harvard Business Review, 84(5), 129-138.

Cooper, R.G. (2011). Winning at new products: Creating value through innovation (4th ed.). New York, USA: Basic Books.

Hamermesh, R.G., Marshall, P.W., \& Pirmohamed, T. (2002). Note on business model analysis for the entrepreneur. Harvard Business School.

Haverila, M. (2011). Mobile phone feature preferences, customer satisfaction and repurchase intent among male users. Australasian Marketing Journal (AMJ), 19(4), 238-246. https://doi.org/10.1016/j.ausmj.2011.05.009

Heinonen, K., Strandvik, T., Mickelsson, K.J., Edvardsson, B., Sundström, E., \& Andersson, P. (2010). A customerdominant logic of service. Journal of Service Management, 21(4), 531-548. https://doi.org/10.1108/09564231011066088

Ibrahim, J., Ros, R.C., Sulaiman, N.F., Nordin, R.C., \& Ze, L. (2014). Positive impact of smartphone application: WhatsApp \& Facebook for online business. International Journal of Scientific and Research Publications, 4(12), 1-4.

Iraqi, Z., Barkany, A.E., \& Biyaali, A.E. (2016). Models of spare parts inventories' optimisation: a literature review. International Journal of Services, Economics and Management, 7(2-4), 95-110. https://doi.org/10.1504/IJSEM.2016.081845

Isoherranen, V., \& Kess, P. (2011). Analysis of strategy focus vs. market share in the mobile phone case business. Technology and Investment, 2(2), 134-141. https://doi.org/10.4236/ti.2011.22014

Johnson, M.W., Christensen, C.M., \& Kagermann, H. (2008). Reinventing your business model. Harvard Business Review, 86(12), 57-68.

Kahn, K.B. (2001). Product planning essentials. USA: Sage Publications.

Kim, H.G., \& Rao, B.M. (2000). Expected warranty cost of two-attribute free-replacement warranties based on a bivariate exponential distribution. Computers \& Industrial Engineering, 38(4), 425-434. https://doi.org/10.1016/S03608352(00)00055-3

Kotler P., \& Keller, K.L. (2009). Marketing management (13th ed.). USA: Pearson Prentice Hall.

Krajewski, L.J., Ritzman, L.P., \& Malhotra, M.K. (2013). Operations management: Processes and supply chains. New York, USA: Pearson.

Krishnan, V., \& Ulrich, K.T. (2001). Product development decisions: A review of the literature. Management Science, 47(1), 1-21. https://doi.org/10.1287/mnsc.47.1.1.10668

Lele, M.M., \& Karmarkar, U.S. (1983). Good product support is smart marketing. Harvard Business Review, 61(6), 124-132.

Lewis, B.R. (1988). Customer care in service organisations. International Journal of Operations \& Production Management, 8(3), 67-75. https://doi.org/10.1108/eb054826

Majava, J., \& Isoherranen, V. (2016, December). Excellence in integrating care into the product development process: A case study of Nokia. Proceedings of the Industrial Engineering and Engineering Management (IEEM), IEEE International Conference in Bali, Indonesia, 1131-1135. https:// doi.org/10.1109/IEEM.2016.7798054

Majava, J., Harkonen, J., \& Haapasalo, H. (2015). The relations between stakeholders and product development drivers: Practitioners' perspectives. International Journal of Innovation and Learning, 17(1), 59-78.

https://doi.org/10.1504/IJIL.2015.066064 
Martinez, V., Bastl, M., Kingston, J., \& Evans, S. (2010). Challenges in transforming manufacturing organisations into product-service providers. Journal of Manufacturing Technology Management, 21(4), 449-469.

https://doi.org/10.1108/17410381011046571

Neely, A. (2008). Exploring the financial consequences of the servitization of manufacturing. Operations Management Research, 1(2), 103-118. https://doi.org/10.1007/s12063-009-0015-5

Oliva, R., \& Kallenberg, R. (2003). Managing the transition from products to services. International Journal of Service Industry Management, 14(2), 160-172. https://doi.org/10.1108/09564230310474138

Osterwalder, A., \& Pigneur, Y. (2010). Business model generation: A handbook for visionaries, game changers, and challengers. Hoboken, New Jersey, USA: John Wiley \& Sons.

Pellicer, P.C., \& Valero, F.A. (2018). Identification of reverse logistics decision types from mathematical models. Journal of Industrial Engineering and Management, 11(2), 239-249. https://doi.org/10.3926/jiem.2530

Puurunen, A., Majava, J., \& Kess, P. (2014). Exploring incomplete information in maintenance materials inventory optimization. Industrial Management \& Data Systems, 114(1), 144-158. https:/ / doi.org/10.1108/IMDS-01-2013-0025

Roy, S.K., Lassar, W.M., Ganguli, S., Nguyen, B., \& Yu, X. (2015). Measuring service quality: a systematic review of literature. International Journal of Services, Economics and Management, 7(1), 24-52.

https://doi.org/10.1504/IJSEM.2015.076322

Saccani, N., Songini, L., \& Gaiardelli, P. (2006). The role and performance measurement of after-sales in the durable consumer goods industries: an empirical study. International Journal of Productivity and Performance Management, 55(3-4), 259-283. https://doi.org/10.1108/17410400610653228

Slack, N., Chambers, S., \& Johnston, R. (2010). Operations management. Harlow: Pearson Education.

Statista (2017). Global market share held by smartphone operating systems. Available at: https://www.statista.com/statistics/263453/global-market-share-held-by-smartphone-operating-systems/ (Accessed: August 2018)

Tien, J.M. (2015). Internet of connected ServGoods: Considerations, consequences and concerns. Journal of Systems Science and Systems Engineering, 24(2), 130-167. https://doi.org/10.1007/s11518-015-5273-1

Ulrich, K., \& Eppinger, S.D. (2000). Product design and development. Singapore: McGraw Hill.

Vargo, S.L., \& Lusch, R.F. (2008). From goods to service(s): Divergences and convergences of logics. Industrial marketing management, 37(3), 254-259. https://doi.org/10.1016/j.indmarman.2007.07.004

Vickery, S.K., Jayaram, J., Droge, C., \& Calantone, R. (2003). The effects of an integrative supply chain strategy on customer service and financial performance: An analysis of direct versus indirect relationships. Journal of Operations Management, 21(5), 523-539. https://doi.org/10.1016/j.jom.2003.02.002

Yin, R.K. (2009). Case study research: Design and methods. Los Angeles, CA, USA: Sage Publications.

Journal of Industrial Engineering and Management, 2019 (www.jiem.org)

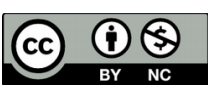

Article's contents are provided on an Attribution-Non Commercial 4.0 Creative commons International License. Readers are allowed to copy, distribute and communicate article's contents, provided the author's and Journal of Industrial Engineering and Management's names are included. It must not be used for commercial purposes. To see the complete license contents, please visit https://creativecommons.org/licenses/by-nc/4.0/. 